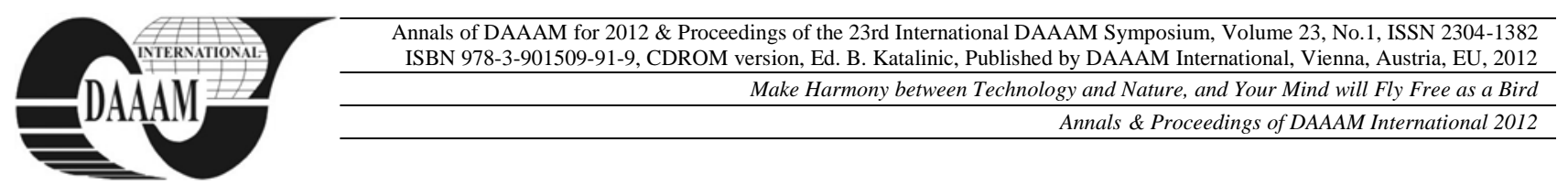

\title{
CLUSTERS AND REGIONAL COMPETITIVENESS IN ROMANIA
}

\author{
CLIPA, R[aluca] I[rina]; POHOATA, I[on]; FILIPEANU, D[umitru] \& TUDOSE, M[ihaela] B[rindusa]
}

\begin{abstract}
Considering the impact of industrial agglomerations on regional competitiveness, the "four clover" model adapted to the Romanian experience and the conclusions drawn from the comparative analysis of region rankings according to the number of clusters, GDP/capita and level of competitiveness, in this article we intend to underline that Romania's regional competitive development can be achieved through an industrial policy based on sustainable competitive clusters. The research methods employed in our study are the logical analysis and the comparative analysis. The paper also suggests issues for further research.
\end{abstract}

Keywords: cluster, pole of competitiveness, innovative cluster, regional competitiveness, policy

\section{INTRODUCTION}

By relying on recent empirical studies on the role of industrial agglomerations over regional economic performance, our article aims at emphasizing the fact that Romania's regional competitive development can be achieved through an industrial policy based on sustainable competitive clusters. The basis of our study is represented by the "four clover" model, adapted to the Romanian experience, and the conclusions drawn from the comparative analysis of region rankings according to the number of clusters, GDP/capita and level of competitiveness.

Although the cluster concept is submitted in literature, it is necessary to define a Romanian concept adapted from the international experience, for a mutual understanding of the term and for a consistent approach for all the stakeholders involved in sustaining the competitiveness of a given cluster.

Moreover, Romania needs to define its policies concerning clusters and poles of competitiveness, taking into account both similar European experiences and Romanian realities. The Romanian public authorities have to focus on the coordination of the activity of clusters within regional and European projects and to facilitate the exchange of best practices with EU Member States and candidate countries.

\section{THE ROLE OF CLUSTERS IN REGIONAL COMPETITIVENESS}

A series of researchers [3] has developed, based on Porter's theories [6], [7], a systematic empirical approach to identify the role of regional clusters - defined as groups of interconnected and complementary industries operating in a particular region - over regional economic performance. Their conclusions were the following: the participating industries from a strong cluster have higher growth rates of occupation, salaries, establishments and patents; new regional industries emerge where a strong cluster already exists; the presence of strong clusters in a given region determines the growth of opportunities in other industries or clusters.

The same group of researchers [4] has studied the role of regional clusters over regional entrepreneurship and has concluded that the presence of complementary economic activities creates externalities which increase incentives and decrease the barriers faced by start-ups. As a result, the industries localized in regions with strong clusters (e.g. characterized by a high presence of other connected industries) confront themselves with a surge in the number of new businesses and enterprises. Influential clusters are also associated with new business establishments, thus influencing decisions regarding business localization. In the end, strong clusters contribute to the survival of start-ups.

The Group of Applied Economics (Grupul de Economie Aplicată - GEA) [8] did a survey on the 42 Romanian counties regarding the correlation between development and entrepreneurial spirit. One of its conclusions showed the existence of several groups of counties with a high performance level - Braşov, Timiş, Cluj, Iaşi, Bihor, Bacău, Galaţi, Prahova, Mureş, Dolj which underlines an equal distribution of entrepreneurial activities over the country's territory, in all the 8 development regions. Based on the logics of the employed methodology, these counties mark the highest degree of entrepreneurial development. Alongside them, the study exposed a number of counties / "isolated" areas - Bucharest, Argeş, Constanţa, Mehedinţi - which singled out for certain reasons: despite the lower levels of some indicators taken into consideration by GEA, there were present other indicators which showed an incredible growth (Bucharest registers high development rates in all areas, but its crime rate is worrisome), as well as particularly developed sectors (such as transport and tourism for Constanta), important companies operating in the area (e.g. Daewoo Automobiles in Dolj, Mittal Steel in Galaţi, Renault in Argeş) and particularly developed industries (e.g. oil extraction in Prahova). Within this context, the first front of entrepreneurial development in Romania is comprised of a sub-nucleus which includes Braşov, Timiş, Bihor, Cluj and Iaşi, to which we add Bucharest, Argeş and Constanţa, areas where strong clusters are currently performing. 
Innovation, a sine qua non condition of economic success and company survival, is currently considered an important factor in ensuring cluster competitiveness. Thanks to Lundvall [2], Nelson's [5] and others researchers contributions to the systemic approach of innovation, the "triple helix" model has been developed. It reunites in the same cluster representatives of: (1) companies (the economic side of the cluster), (2) universities and research institutes (providers of innovative applicable solutions to the real needs of the enterprises in the cluster) and (3) public authorities (local, regional etc.).

\section{THE CLUSTER AND POLE OF COMPETITIVENESS CONCEPTS}

Michael E. Porter [6], the founder of the economic policy based on industrial agglomerations, defines clusters as a concentration of companies and associated enterprises (universities, research institutes, trial laboratories, standardisation organisations, continuous professional learning providers, professional associations, local authorities etc.) from a specific field, found in the same geographical area and interconnected through common and complementary activities. The definition underlines the interrelations between actors, the synergies and positive externalities generated by their collaboration, such as a qualified local workforce, reduced transportation costs, external economies of scale, technology and know-how transfer etc.

The European Comission defines the cluster concept as a group of companies, entities and institutions that are economically interconnected and located near each other and have reached a sufficient scale to develop specialized expertise, services, resources, suppliers and skills.

The term cluster is also found in the Romanian legislation (GD 918:2006 - "Impact" Programme), being defined as a concentration of producers, users and/or beneficiaries, with the purpose of applying EU good practice in order to increase the competitiveness of economic agents.

The common element of these definitions is the geographical proximity of the entities forming a cluster, hence the main characteristic of a cluster, which takes into consideration the transportation and communication facilities, as well as existing cultural identities, traditions and customer preferences.

An important stress falls on the following features of clusters as well: technological proximity (how close to each other are the technologies used by companies from a certain cluster), social proximity (the levels and types of interactions between managers and employees of the companies forming a cluster), complementarity of workforce and clients. The firms concentrated in a cluster do not have to question whether to compete or cooperate, but on which levels to compete and on which to cooperate.

According to the Guide for the development of competitiveness poles in Romania, published in September 2011 by the MA SOPIEC "The Management
Authority for the Sectoral Operational Programme 'Increase of Economic Competitiveness' " [9], the competitiveness pole represents an association, existing in a defined geographical area, between enterprises and research organisms or educational institutions with research interests, found in a partenerial collaboration (a crucial element being their common development strategy), with the purpose of generating synergies around a series of innovative projects focused on one or several markets. Within poles of competitiveness, the aim is to enhance the interactions between firms, academic institutions and other entities involved in supporting the business environment and in guiding the private sector towards innovation and technological transfer.

\section{INDUSTRIAL AGGLOMERATIONS IN ROMANIA - EMPIRICAL EVIDENCES}

In Romania, there have been created, in a natural manner, approximately 26 innovative clusters and regional poles of competitiveness, in different economic sectors: automotive industry, ITC, creative industries, renewable energies, aviation, maritime industry, food industry, tourism, as well as 49 industrial parks with circa 760 enterprises from different sectors.

The Clusters and Potential Clusters in Romania - a Mapping Exercise [1] report identified, at the first level of analysis, a number of 55 clusters and potential clusters in the 8 Romanian regions, an average of 7 clusters per region. This underlines a balanced regional cluster distribution in the country.

In order to identify the clusters, the so-called "peerreview" methodology was employed in all the 8 regions. The analytical base for the cluster review is represented by a cluster concept developed for the purpose of this study, based on an altered "triple helix" approach. In its centre there are five vectors which can be viewed as success factors for clusters in general and which were later used as a structure for the analysis: concentration, research-development units, workforce, cooperation and service providers.

Therefore, they identified a number of 55 clusters, an average of 7 clusters/region. The analysis revealed that in the 55 clusters distinguished in the first stage, the workforce and human capital resources are fairly good. However, cooperation occurs with difficulty, and the availability and usage of specific innovative services is insufficient.

In this context, it is necessary to establish which of the identified clusters are real. Even after the second review, during which 2 important vectors were monitored, "cooperation" and "services providers", the balanced regional distribution of clusters was maintained (between 2 and 4 industrial agglomerations per region).

Currently Romania has a total of 19 innovative clusters (with an agreement of collaboration) and by 2012 it is estimates that other 4 innovative clusters in aviation, shipbuilding, renewable energies and automotive will be created. 
In Romania, experience has shown that the 3 natural components of the "triple helix" do not cooperate, thus arising the need to adapt the model and to transform it into the "four clover" one, the fourth component being the so-called catalyst organizations: consultancy firms specialized in the transfer of technology and innovation, centers of technological transfer, chambers of commerce etc [1].

Romanian clusters and competitiveness poles do not have a legal personality, they are created based on a collaboration protocol signed and sealed by all its members, but the management association of the associative structure does have a juridical personality.

\section{TOWARDS A CLUSTER-SUSTAINING INDUSTRIAL POLICY}

The comparative analysis of region rankings according to the number of clusters and GDP/capita (Tab.1, a and b) provides us with an interesting observation. The top position, with 8 clusters in the same region, is occupied by the Bucharest-Ilfov and Western regions, which are also ranked the highest within GDP/capita line up. However, the North-East and SouthMuntenia regions, with 8 clusters each as well, occupy the last positions within GDP/capita ranking, on the eighth and fifth place. For the latter, industrial agglomerations have not generated regional performance.

\begin{tabular}{|c|c|c|c|}
\hline Region & $\begin{array}{c}\text { Ranking } \\
\text { according to } \\
\text { the number of } \\
\text { clusters/region } \\
\text { (a)* }\end{array}$ & $\begin{array}{c}\text { Ranking } \\
\text { according } \\
\text { to } \\
\text { GDP/capita } \\
\text { (b)** }\end{array}$ & $\begin{array}{c}\text { Ranking } \\
\text { according to } \\
\text { competitiveness } \\
\text { (c)*** }\end{array}$ \\
\hline North-East & $1(8)$ & $8(59,0)$ & 6 \\
\hline South-East & $4(5)$ & $6(80,5)$ & 8 \\
\hline $\begin{array}{c}\text { South- } \\
\text { Muntenia }\end{array}$ & $1(8)$ & $5(88,1)$ & 5 \\
\hline South-West & $3(6)$ & $7(74,3)$ & 7 \\
\hline West & $1(8)$ & $2(111,3)$ & 2 \\
\hline $\begin{array}{c}\text { North-West } \\
\text { Centre }\end{array}$ & $2(7)$ & $4(90,9)$ & 3 \\
\hline Bucharest- & $1(8)$ & $3(95,3)$ & 4 \\
\hline Ilfov & $1(239,7)$ & 1 \\
\hline
\end{tabular}

Tab.1. Region rankings - comparative analysis

$*$ the 2010 Mapping Report index ; ** the 2010 National Comission of Prognosis index, by relating the regional level to the national level (\%); **** the 2005 GEA index

If we take into consideration the ranking of regions according to their level competitiveness (Tab.1, c), we observe that the North-Western and Central regions top the ranking of Romania's most competitive regions (they are third and fourth-ranked), but their success is not due to a coherent support policy for regional cluster development. So far, Romania has not benefited from a policy based on the development of industrial agglomerations, which, in turn, could have led to the improvement of regional competitiveness.
In addition to that, Romania's lack of a cohesive cluster-financing framework has acted as a decelerator in the development of clusters. We believe that this obstacle will be overcome once the European structural funds from the SOP IEC "Sectoral Operational Programme 'Increase of Economic Competitiveness' " will be accessed by the poles of competitiveness, starting from 2012, in order to attract SMEs in provider chains and clusters.

Although very different among themselves, clustersupport policies can be divided into 3 main categories, depending on the objectives and reasons which led to their implementation:

- Facilitation policies, directed towards the creation of a micro-economic environment favourable to development and innovation, indirectly facilitating the emergence and development of clusters;

- Traditional framework policies, which include policies for SMEs and industry, for research and innovation, regional policies; they refer to clusters as instruments for improving their efficiency;

- Development policies, centred on the creation and mobilisation of a specific category of clusters, with the purpose of reinforcing a certain economic sector. This is the only category which directly concerns the cluster theory.

Previous experience of other European economies shows 2 types of cluster-support schemes: the first one supports "top-level" clusters, with influence on the level of competitiveness of the respective country and susceptible of reaching an international excellence degree; the second type deals with regional clusters, whose importance may not surpass the region's borders, but which have a considerable impact on the overall economic development.

In Romania's case, we believe that a third type of cluster-support policies is necessary, focused on the processes prior to cluster formation, in order to facilitate cooperation between partners, much needed for subsequent cluster development.

A crucial element for the cluster-support policies is represented by the programmes of partners instruction, a financing solution for them being the structural funds from SOP DHR "Sectoral Operational Programme 'Development of Human Resources' ", for the development of personnel. Moreover, the development of an infrastructure for clusters is also necessary, a financing solution being the structural funds from ROP "Regional Operational Programme".

At the same time, the public authorities have to understand that cluster development is a market driven phenomenon, following a bottom up approach, where an entrepreneurial mindset is a key ingredient. Public authorities can play an important role in supporting cluster development, by cutting down administrative hurdles, promoting national platforms for information (sharing, support schemes). The role of the public authorities must not be confused with "governance" of clusters (see collaboration agreements and partnerships as well as identifying business opportunities). 
Moreover, the public authorities have to focus on the coordination of the activity of clusters within regional and European projects and to facilitate the exchange of best practices with EU Member States and candidate countries.

To underpin this objective, on July 1, 2011, the National Agency of Clusters was created, while the Romanian Ministry of Economy, Commerce and Business Environment became a member of ECA European Cluster Alliance.

In addition to that, the Ministry supports the competitiveness of innovative clusters through a new project within the Sectoral plan of industrial research, while also including them in a series of regional programmes (South-Eastern Europe, Black Sea Basin, Danube Strategy etc.) or EU economic missions (France, Germany, Sweden, Italy, Hungary, Slovenia etc.), to promote experience and good practice exchange.

\section{CONCLUSIONS}

The cluster concept, adopted from European experience, is defined in the Romanian legislation as a concentration of producers, users and/or beneficiaries, with the purpose of applying EU good practice in order to increase the competitiveness of economic agents.

The comparative analysis of region rankings according to the number of clusters, GDP/capita and competitiveness index underlines the fact that, so far, the development of industrial agglomerations has not offered any support for the regional competitiveness in Romania.

The analysis was based on the 2010 Mapping Report index for the ranking according to the number of clusters/region, on the 2010 National Comission of Prognosis index for the ranking according to GDP/capita and on the 2005 GEA index for the ranking according to competitiveness. The limitations of the research and the author's approach lies in the difficulty of data collection for comparable time periods, so that findings could be falsified.

The "four clover" model, adapted to the Romanian realities, has suggested, under a normative aspect, a third type of policies for supporting clusters, policies oriented towards the processes prior to cluster formation, with the purpose of facilitating partner cooperation.

Currently, Romania has a total of 19 innovative clusters (with an agreement of collaboration) and by 2012 it is estimated that other 4 innovative clusters in aviation, shipbuilding, renewable energies and automotive industry will be created.

In Romania, there is a significant potential for the development of competitive clusters, as the 2010 Cluster Mapping showed a balanced regional distribution of clusters on its territory. Furthermore, all of its 8 development regions meet the requirements of cluster formation - the presence of all the four clover petals: business and industry; higher-education institutions and a research-development-innovation environment; local and regional authorities; catalysts - innovation and technological transfer entities, chambers of commerce, consultancy firms.

The Romanian Government's strategic plans deal with the promotion of clusters and supplier chains, with the investment in new technologies, while encouraging international cooperation, as well as stimulating cooperation between universities, research institutes and innovative SMEs. One of the major objectives of our regional development strategies has to be concerned with the identification of those interest areas that favour the development of regional clusters and with the necessary accompanying measures.

The questions that we need to address are: just how competitive are clusters? How strong are the synergies created by them? What is the impact of industrial agglomerations over regional competitiveness in Romania? All these inquiries can inspire future empirical research in this field.

\section{ACKNOWLEDGEMENTS}

This work was supported by the project "PostDoctoral Studies in Economics: training program for elite researchers - SPODE" co-funded from the European Social Fund through the Development of Human Resources Operational Programme 2007-2013, contract no. POSDRU/89/1.5/S/61755.

\section{REFERENCES}

[1] Cosnita, D., Guth, M. (2010). Report on the Cluster Mapping Results. Bucharest: Romanian Ministry of Economy and gtz. Available from http://www.minind.ro/presa_2010/iulie/ MappingReport_230710.pdf Accessed: 2012-03-21

[2] Lundvall, B-Å. (1992) (ed.). National Systems of Innovation: Towards a Theory of Innovation and Interactive learning, London: Pinter Publishers

[3] Mercedes Delgado, Michael E. Porter, Scott Stern (2010 a), Clusters, Convergence, and Economic Performance, US Census Bureau Center for Economic Studies Paper No. CES-WP- 10-34, October 1, 2010, Available from http://dx.doi.org/10.2139/ssrn.1695011 Accessed: 2012-02-16

[4] Mercedes Delgado, Michael E. Porter, Scott Stern (2010 b), Clusters and entrepreneurship, Journal of Economic Geography, Vol. 10 No. 4 (July 2010), pp. 495-518, ISSN 1468-2710

[5] Nelson, R.R. (1993) (ed.). National Innovation Systems: A Comparative Analysis, Oxford: Oxford University Press, ISBN13: 978-0195076172

[6] Porter, M.E. (1998). Cluster and the new economics of competition. Harvard Business Review. Vol. 76, No. 6 (Nov/Dec, 1998), pp. 77-90, ISSN 00178012

[7] Porter, M.E. (2003). The Economic Performance of Regions, Presentation the Indiana Leadership Summit Indianapolis, Indiana, May 13th, 2003, Available from http://www.isc.hbs.edu/pdf/Indiana_Leadership_Summit_2003.05 13.pdf Accessed: 2012-02-25

[8] Group of Applied Economics (GEA) (2007), Manual for assessing regional competitiveness, Bucharest, August 2007, Available from http://www.gea.org.ro/documente/ro/proiecte/ manual_2007.pdf Accessed: 2012-01-22

[9] AM POSCCE (2009). Ghid pentru implementarea în România a conceptului de cluster inovativ / Guide for the implementation in Romania of the concept of innovative cluster, Bucharest: Irecson, ISBN 978-973-7694-66-9 